\title{
Genome-wide identification and expression analysis of the GhIQD gene family in upland cotton (Gossypium hirsutum L.)
}

Lingling Dou ( $\nabla$ xjyldll@126.com )

Xianyang Normal University https://orcid.org/0000-0001-5309-9452

Limin Lv

Institute of cotton research of Chinese Academy of agriculture sciences

Huaizhu Li

Xianyang Normal University

Yuhong Li

Xianyang Normal University

Ruimin Xi

Xianyang Normal University

Qin Zhao

Xianyang Normal University

Wenbo Wang

Xianyang Normal University

Chaoyou Pang

state key laboratory of cotton research

Changsong Zou

Henan University

Guoli Song

Insstitute of Cotton Research of Chinese Academy of Agricultural Sciences

Guanghui Xiao

Shaanxi Normal University

\section{Research article}

Keywords: Gossypium hirsutum L., GhIQD genes, segmental duplication, expression analysis

Posted Date: November 1st, 2019

DOI: https://doi.org/10.21203/rs.2.16724/v1 
License: (c) (i) This work is licensed under a Creative Commons Attribution 4.0 International License. Read Full License

Version of Record: A version of this preprint was published at Journal of Cotton Research on February 3rd, 2021. See the published version at https://doi.org/10.1186/s42397-021-00079-3. 


\section{Abstract}

Background: Calmodulin (CaM) is one of the most important $\mathrm{Ca} 2+$ signaling receptors because it regulates diverse physiological and biochemical reactions in plants. CaM functions by interacting with CaM-binding proteins (CaMBPs) to modulate Ca 2+ signaling. IQ domain (IQD) proteins are plant-specific CaMBPs that bind to CaM by its specific CaM binding sites. Result: In this study, we firstly identified 102 GhIQD genes in the Gossypium hirsutum L. genome. The GhIQD gene family was classified into seven clusters (la, Ib, Ic, II, IIla, IIIb and IV), and we then mapped the GhIQD genes to the 26 chromosomes. Moreover, we found that 100 of the 102 GhIQD genes resulted from segmental duplication events, indicating that segmental duplication is the main force driving GhIQD gene expansion. Gene expression pattern analysis showed that a total of 89 GhIQD genes are expressed in the elongation stage and second cell wall biosynthesis stage of the fiber cells, suggesting that GhIQD genes may contribute to fiber cell development in cotton. In addition, we found that 20 randomly-selected GhIQD genes were highly expressed in different tissues. Exogenous application of MeJA significantly enhanced the expression levels of GhIQD genes. Conclusion: Our study shows that GhIQD genes are involved in fiber cell development in cotton and are also widely induced by MeJA, which provides a basis to systematically characterize the evolution and biological functions of GhIQD genes, as well as clues to breed better cotton varieties in the future.

\section{Background}

Calcium signaling is one of the most important cytosolic second messages that mediates various developmental processes and the responses to biotic and abiotic stresses [1]. Cytoplasmic $\mathrm{Ca}^{2+}$ signals exert their functions through changes in the $\mathrm{Ca}^{2+}$ concentration with spatiotemporal specificity [2], and can be induced by extracellular stimuli such as drought, salt-alkali stress, and light, or intracellular stimuli such as plant hormones and pathogenic factors [3]. In stimulated cells, cytoplasmic $\mathrm{Ca}^{2+}$ levels show significant transient increases or changes in their concentration gradients or regional distribution [4]. $\mathrm{Ca}^{2+}$ ions can be detected and decoded by calcium-binding proteins known as $\mathrm{Ca}^{2+}$ receptors, which then transduce the signals into a series of downstream effects [5], including the dephosphorylation or phosphorylation of target proteins [6]. Most $\mathrm{Ca}^{2+}$ receptor proteins contain helix-loop-helix fold (EF-hand) motifs that act as $\mathrm{Ca}^{2+}$-binding domains. In higher plants, the calcium receptor proteins can be divided into four categories [7]: Calmodulin (CaM), CaM-like proteins (CML), calcineurin B-like proteins (CBL), and calcium-dependent protein kinases (CDPK) [8], all of which contain EF-hand motifs.

CaM is widely distributed in eukaryotic cells. Among the known signal transduction pathways, CaMmediated signal transduction has been shown to be the main pathway that functions in plants [1,9]. CaM is highly conserved and stable, and both the $\mathrm{C}$ - and $\mathrm{N}$-termini contain two spherical domains that are connected by a-helix motifs. Every spherical domain has an EF-hand motif, which is a $\mathrm{Ca}^{2+}$ ion-binding domain. One CaM molecule can bind four $\mathrm{Ca}^{2+}$ ions. The combination of $\mathrm{Ca}^{2+}$ with $\mathrm{CaM}$ forms the $\mathrm{Ca} / \mathrm{CaM}$ complex, which changes the conformation of $\mathrm{CaM}$, exposing the negatively charged 
hydrophobic surface in the spherical region and playing a role in the interaction between CaM and target proteins [10]. CaM that is not combined with $\mathrm{Ca}^{2+}$ ions, known as apocalmodulin (ApoCaM), functions by combining with $\mathrm{Ca}^{2+}$-independent CaMBP to transmit signals in low-Ca ${ }^{2+}$ conditions $[11,12]$. Thus, the identification and analysis of CaMBPs is important to illustrate the various functions of CaM in signal transduction processes.

CaM is one of the most important $\mathrm{Ca}^{2+}$ signaling receptors [13], and it regulates diverse physiological and biochemical reactions. However, CaM has no enzymatic activity and transmits signals by interacting with CaM-binding proteins to modulate cellular physiology [14]. CaM-binding proteins (CaMBPs) play important roles between $\mathrm{Ca}^{2+}$ and $\mathrm{CaM}$ and are the target proteins of the direct action of CaM. CaMBPs can be divided into two classes that are $\mathrm{Ca}^{2+}$-dependent or $\mathrm{Ca}^{2+}$-independent [1]. The IQ motif was the firstly identified $\mathrm{Ca}^{2+}$-independent CaM-binding motif. In plants, the proteins containing IQ motifs include the myosin protein family, the calmodulin-binding transcription activator (CAMTA) protein family, the cyclic nucleotide-gated channel (CNGC) protein family, the IQ-motif containing (IQM) protein family, and the IQ67-domain containing (IQD) protein family [15]. IQD gene family members, plant-specific CaM/CMLbinding proteins (CaMBPs), were firstly reported in Arabidopsis and rice and are [16]. They are characterized by domains consisting of 67 amino acid residues, such as the IQ67 domain, that are defined by a unique repetitive arrangement of the IQ motif; the $\mathrm{Ca}^{2+}$-dependent CaM recruitment motifs exhibit 1-5-10 and 1-8-14 arrangements [17].

Plant-specific IQD gene families have been analyzed in Populus trichocarpa [8], Arabidopsis thaliana, Oryza sativa [16], Phyllostachys edulis [18], Glycine max [19], and Solanum lycopersicum [20], and the functions of a few IQD genes have been reported. In tomato, the SUN genes and other members of the IQD gene family exert their effects on organ shape by interacting with microtubules [15]. In A. thaliana, AtIQD5 regulates pavement cell morphogenesis via $\mathrm{Ca}^{2+}$ signals [21]. The tomato IQD gene SUN24 regulates seed germination through the abscisic acid (ABA) signaling pathway [22]. The AtIQD1 protein localizes to microtubules and interacts with kinesin light chain-related protein 1 (KLCR1) to facilitate the cellular transport of specific cargo [17]. PtIQD genes show tissue-specific expression patterns and could also be regulated by drought and methyl jasmonate (MeJA) stresses [8]. Additionally, some of the GmIQD genes are expressed specifically and could be regulated by MeJA stress [19].

Upland cotton (Gossypium hirsutum L.) is one of the most important economic crops worldwide, because it provides raw materials for the textile industry as well as an edible oil for food use. Therefore, $G$.

hirsutum $L$. fiber production and quality are very important. However, the production is greatly affacted by abiotic and biotic stresses. For example, in China, aphid infestation has been found to reduce G. hirsutum L. production by $30 \%$ [23], and salt stress has been shown to decrease cotton fiber production by $20 \%$ [24]. IQD proteins are CaMBPs that play important roles in plant stress signal transduction. However, these proteins have not been reported in G. hirsutum L. In this study, we firstly identified 102 GhIQD genes and determined their chromosomal locations, predicted protein physicochemical properties, duplications, phylogenetic relationships, and expression patterns during fiber development at 5, 10, 15, and 25 days 
post anthesis (dpa). Twenty selected GhIQD genes were selected for the analysis of tissue-specific expression patterns and their response to MeJA stress. These preliminary results for the GhIQD genes provide the foundation for further research on the physiological and biochemical functions of IQD proteins in G. hirsutum L.

\section{Results}

\section{Identification of GhIQD gene family members in G. hirsutum $L$.}

In order to identify IQD gene family members in G. hirsutum L., 36 Arabidopsis IQD protein sequences were used as queries to search the allotetraploid cotton genome database. After the further selection of conserved domains, a total of 102 IQD genes from the $G$. hirsutum $\mathrm{L}$. genome were identified as members of the GhIQD gene family. The chromosomal locations of the GhIQD genes were then determined using the allotetraploid cotton genome information [25]. As a result, all of the GhIQD genes were mapped to the 26 chromosomes and named GhIQDA01.1 to GhIQDD13.12 based on their relative positions on the chromosomes (Table 1, Fig. 1). The number of amino acids (aa) in the predicted GhIQD protein sequences ranged from 120 (GhIQDA02.3) to 900 aa (GhIQDA05.6) with an average length of 458 aa, and the open reading frames (ORFs) ranged from 363 base pairs (bp) to $2703 \mathrm{bp}$ with an average length of $1377 \mathrm{bp}$. The molecular weights (MWs) of the proteins encoded by these proteins varied from 13,689.84 Daltons (Da) (GhIQDA02.3) to 99,360.68 Da (GhIQDD05.6), with an average MW of 51,151.02 Da. Based on isoelectric point (pl) analysis, the calculated pls of the 96 GhIQD genes were $>7.0$ (with an average of 10.27), whereas six GhIQD genes were predicted to encode proteins with pls $<7.0$ (average of 6.05), including GhIQDD06.1, GhIQDA01.2, GhIQDA06.1, GhIQDD01.2, GhIQDD05.6, and GhIQDA05.6. The predicted subcellular localizations showed that 82 GhIQD proteins localize to the nucleus, nine GhIQD proteins localize to the mitochondria, nine GhIQD proteins localize to the chloroplasts, and two GhIQD proteins were found to localize to the endoplasmic reticulum (ER) (Table 1).

IQD proteins are reported to specifically bind to calcium via CaM-binding sites[26]. To better explore the biological functions of GhIQD proteins, the CaM-binding sites of the GhIQD proteins were predicted using the online Calmodulin Target Database software. As a result, GhIQD proteins are predicted to contain CaM-binding sites. Multiple consecutive strings of amino acid residues with scores $>7$ are given in Additional file 1. This result suggests that all GhIQD proteins contain CaM-binding sites with 1-3 strings of high-scoring amino acid residues. Based on the whole-genome duplication analysis in G. hirsutum L., $5926(8.14 \%)$ and 55707 (76.56\%) genes originated from tandem and segmental duplication, respectively. Therefore, we investigated the role of duplication events in the evolution of GhIQD genes. As shown in Fig. 2, among the 102 GhIQD genes identified in G. hirsutum L., 100 (98.04\%) were derived from segmental duplication events, and only two genes (GhIQDA13.3 and GhIQDD13.3) resulted from proximal duplication. In contrast, none of the GhIQD genes was found to have arisen from tandem duplication events (Additional files 2 and 3 ). These results indicate that segmental duplication is the main driving force in the expansion of the GhIQD genes. 


\section{Phylogenetic analysis of GhIQD proteins}

To examine the molecular evolutionary relationships among plant IQD proteins, the amino acid sequences of the IQD proteins from Arabidopsis, tomato, soybean, and G. hirsutum L. were used in a phylogenetic analysis. As shown in Fig. 3, a phylogenetic tree was constructed with the Neighbor-Joining $(\mathrm{NJ})$ method from an alignment of all complete IQD protein sequences. The NJ tree showed that the IQD proteins group into seven clusters (la, Ib, Ic, II, IIla, IIIb and IV).

$\mathrm{A} \mathrm{Ka/Ks} \mathrm{ratio} 1>$ indicates that paralogous gene pairs were produced by positive selection, a ratio $<1$ indicates that paralogous gene pairs were under purifying selection and a ratio equal to 1 indicates that paralogous gene pairs were not subjected to selection pressure [27]. To explore the type selection pressure experienced by the duplicated GhIQD genes, paralogous GhIQD gene pairs were used to calculate synonymous (Ks) and non-synonymous (Ka) substitution rates to assess the ratio of non-snonymous to synonymous substitutions. As shown in Fig. 3, 50 paralogous gene pairs were identified. The $\mathrm{Ka} / \mathrm{Ks}$ ratios of 48 members were $<1.0$, and the $\mathrm{Ka} / \mathrm{Ks}$ ratios for the remaning two paralogous gene pairs were $>1$ (Additional file 4), suggesting that the GhIQD paralogous gene pairs were mainly produced by purifying selection.

\section{Expression profiling of GhIQD genes during fiber development}

Gene expression profiling can provide us with clues about the possible biological functions of genes. Therefore, we analyzed the gene expression profiles of GhIQD genes using the transcriptome data downloaded from the publicly available CottonFGD database. As shown in Fig. 4, a total of 89 GhIQD genes are expressed during the developmental process in fiber cells. Based on the heatmap, six clusters of GhIQD genes are predominately expressed in cotton fiber cells (Fig. 4a). In detail, the 13 GhIQD genes in cluster 2 were highly expressed in fiber cells at 5 days post anthesis (dpa); the expression levels of 17 GhIQD family members in cluster 5 were up-regulated in the 10 dpa samples; 21 genes in cluster 3 were significantly expressed in fibers at $20 \mathrm{dpa}$; genes in cluster 1 with 21 members were highly expressed in $25 \mathrm{dpa}$ fiber cells; in cluster 4, the transcripts of seven genes were abundant in fibers at 20 and $25 \mathrm{dpa}$; and the remaning 10 GhIQDs in cluster 6 were highly expressed in the 5 dpa and 25 dpa samples (Fig. $4 b)$. These results imply that GhIQD genes may function in fiber cell development in cotton.

\section{Tissue-specific expression analysis of GhIQD genes by quantitative real time-PCR (qRT-PCR)}

The GhIQD gene family has 102 members; of these, 20 genes were randomly selected to investigate their expression patterns in different tissues, including the calyx, leaf, stigma, stem, root, petal, pollen, and hypocotyl. As shown in Fig. 5, GhIQDD12.1, GhIQDA13.1, and GhIQDD13.1 were predominantly expressed in pollen (Fig. $5 \mathrm{~d}$ ), indicating that these genes may play pivotal roles in pollen development. GhIQDD01.3. GhIQDD01.2, and GhIQDD05.2 showed stem-specific expression (Fig. 5b), and GhIQDA01.1, GhIQDA05.2, and GhIQDA08.1 were expressed preferentially in leaves (Fig. 5a). The GhIQDA06.1, GhIQDD06.1, and GhIQDD09.1 genes showed higher expression levels in leaves and stems (Fig. 5c). Most genes investigated were abundantly expressed in different tissues (Fig. 5e), as observed for GhIQDA02.1 and 
GhIQDD02.1 that were highly expressed in all tissues with similar expression patterns. The cluster II genes, GhIQDA12.3 and GhIQDD12.4, were highly expressed in the leaf, petal, and hypocotyl (Fig. 5e).

\section{Expression profiling of GhIQD genes in response to MeJA treatment}

According to previous studies, the expression of most IQD genes can be induced by MeJA stress in plants [22] In this study, the expression patterns of GhIQD genes in plants exposed to MeJA treatment were examined in an qRT-PCR experiment. The results showed that the expression levels of the 20 randomlyselected GhIQD genes were significantly increased by MeJA treatment (Fig. 6). As the time of treatment increased, the transcript levels for most genes increased significantly. In detail, the expression levels of GhIQDD01.3, GhIQDA09.3, GhIQDD02.1. GhIQDD05.2, GhIQDD09.1, GhIQDD13.1 and GhIQDA13.1 were induced from $0 \mathrm{~h}$, with the highest expression levels detected at 12 and $24 \mathrm{~h}$ after the MeJA treatment. The GhIQDA06.1, GhIQDD06.1, and GhIQDD09.4 genes also exhibited the highest expression levels at $24 \mathrm{~h}$ after the MeJA treatment. The expression levels of GhIQDD01.2, GhIQDA13.4, GhIQD12.4, GhIQDD12.1, GhIQDA12.3, GhIQDA08.1, GhIQDA01.1 and GhIQDA02.1 peaked at $6 \mathrm{~h}$ after the treatment. Compared with the other genes, the maximum expression of GhIQDA05.5 occurred at $72 \mathrm{~h}$. These results showed that the GhIQD genes are widely induced by MeJA treatment.

\section{Discussion}

Calcium is one of the most important cytosolic second messengers, and calcium levels can be induced by intracellular and extracellular stimuli. $\mathrm{CaM}$ is one of the most important $\mathrm{Ca}^{2+}$ signaling receptors that regulates diverse physiological and biochemical reactions. CaM functions by interacting with $\mathrm{CaM}-$ binding proteins (CaMBPs) to modulate cellular physiology. IQD proteins are plant-specific $\mathrm{CaM} / \mathrm{CML}$ CaMBPs that are characterized by 67-amino acid domains. In this study, we firstly identified 102 GhIQD genes in G.hirsutum and analyzed their chromosomal locations, protein physicochemical properties, gene duplication events, phylogenetic relationships, and expression patterns during development of fiber cells. Twenty randomly selected GhIQD genes were used for the analysis of tissue-specific expression patterns and their response to MeJA treatment.

\section{The GhIQD gene family expanded by segmental duplication}

A number of IQD genes have been reported in different plants; there are 33 AtIQD genes in A. thaliana, 28 OsIQD genes in Oryza sativa [16], 38 PtIQD genes in Populus trichocarpa [8], 29 PelQD genes in Phyllostachys edulis (moso bamboo) [18], 67 GmIQD genes in Glycine max [19], and 34 SISUN/ IQD genes in Solanum lycopersicum [20]. In this study, a total of 102 GhIQD genes were identified in G. hirsutum L. The number of $I Q D$ genes in $G$. hirsutum $\mathrm{L}$. is greater than that found in other plant species, possibly because $G$. hirsutum $L$. is an allotetraploid cotton species that originated from the hybridization of $G$. arboreum and G. raimondii and subsequent polyploidization 1-2 million years ago [25]. A whole-genome duplication analysis showed that 100 of the GhIQD genes arose from segmental duplication, and the other two genes, GhIQDA13.3 and GhIQDD13.3, originated from proximal duplications. Additionally, Ka/Ks 
analysis indicated that most of the GhIQD genes were under purifying selection, which indicates that the segmentally duplicated GhIQD genes were subjected to strong purifying constraints during evolution.

\section{GhIQD genes participate widely in the regulation of growth in $G$. hirsutum L.}

In Arabidopsis, the AtIQD proteins were reported to widely link calcium signaling to microtubules, membrane subdomains, and the nucleus [28]. From the results of the transcriptome analysis, the GhIQD gene expression patterns could be clustered into six groups. In the fiber development process, the $5 \mathrm{dpa}$ ovule stage is primary cell wall synthesis stage of fiber cells; $10 \mathrm{dpa}$ corresponds to the elongation stage of fiber development; and 20-25 dpa is the transition stage of fiber development from elongation to secondary wall synthesis, which is important for fiber strength [29]. PdIQD10 gene was found to involve in the secondary cell wall biosynthesis and biomass formation in Populus [30]. Therefore, the genes in cluster 6 might participate in primary cell wall synthesis, the GhIQD genes in cluster 5 may contribute to fiber elongation, and the GhIQD genes in clusters 1, 3, and 4 may be involved in fiber strength development.

In Arabidopsis, AtIQD genes function as hubs in $\mathrm{Ca}^{2+}$ signaling to regulate growth and development with tissue-specifically [31]. To further elucidate the possible functions of the GhIQD genes, their expression patterns were investigated in various tissues (Fig. 5). The results show that some GhIQD genes are predominantly expressed in specific tissues, and the paralogous gene pairs exhibit similar expression patterns, such as GhIQDA13.1 and GhIQDD13.1, which are predominantly expressed in pollen, indicating that GhIQD gene pairs are functionally redundant.

MeJA is an ester of jasmonic acid and is widely present in plants[32]. MeJA triggers the biosynthesis of plant defensive compounds and initiates the expression of pathogenesis-related genes involved in systemic acquired resistance and local resistance [33]. In this study, the expression levels of all 20 selected GhIQD genes were increased (Fig. 6) in response to MeJA treatment, which is consistent with previous studies showing that most of the IQD genes in $P$. trichocarpa and moso bamboo are induced by MeJA treatment $[8,18]$. These results imply that the IQD gene family plays an important role in tolerance to MeJA abiotic stress in plants.

\section{Conclusion}

In conclusion, we identified 102 GhIQD genes in G. hirsutum L. Segmental duplication was the main driving force behind the expansion of the GhIQD family. Ka/Ks analysis showed that GhIQD genes were under purifying selection. Based on the expression analysis, 89 genes could be detected during the stages of fiber development; tissue-specific expression analysis showed that some of the GhIQD genes were specifically expressed; and all 20 selected GhIQD genes could be induced by MeJA treatment. These preliminary results provide the foundation for further research on the physiological and biochemical functions of IQD proteins in G. hirsutum L. 


\section{Methods}

\section{Identification of GhIQD gene family members in G. hirsutum $L$.}

To identify GhIQD gene family members in G. hirsutum L., the G. hirsutum L. genome [25] sequences were downloaded from the Cotton Functional Genomics Database (CottonFGD, https://cottonfgd.org/about/download.html). The AtIQD protein sequences from $A$. thaliana were downloaded from The Arabidopsis Information Resource (TAIR, https://www.arabidopsis.org/index.jsp), and the IQD protein sequences from Glycine max and Solanum lycopersicum were downloaded from Phytozome (https://phytozome.jgi.doe.gov/pz/portal.html). The G. hirsutum L. genome sequences were searched using a Basic Local Blastp search against reported IQD proteins, including 34 SISUN, 27 OsIQD, $66 \mathrm{GmIQD}$, and 33 AtIQD proteins. The redundant sequences were removed manually. We also used a Hidden Markov Model (HMM) with the default parameters to search the G. hirsutum L. genome for IQD proteins (PF00612) in the Pfam database (http://pfam.xfam.org), and the SMART databases (http://smart.embl-heidelberg.de) were used to confirm that all the candidate sequences were members of the IQD family [34]. The identified sequences were named according to their physical locations on the 26 G. hirsutum L. chromosomes and were visualized with MapChart 2.2 software [35].

The isoelectric point $(\mathrm{pl})$ and molecular weight $(\mathrm{MW})$ were predicted for each protein with the online software ExPASy (https://www.expasy.org/tools/). The subcellular localization of GhIQD proteins was predicted using WoLF PSORT (https://wolfpsort.hgc.jp).

\section{GhIQD protein sequence Alignment and Phylogenetic Analysis}

A multiple alignment of all the predicted IQD protein sequences from maize, soybean, bamboo, Arabidopsis, tomato, and G. hirsutum L. was performed with MEGA version 7 [36, 37].

\section{Gene Duplication and Synteny Analysis of GhIQD genes}

The duplication pattern of each GhIQD gene was analyzed using MCScanX software according to the instruction manual [38]. The whole-genome BLASTP analysis of G. hirsutum L. was performed using local Blast software considering e-values of less than $1 \mathrm{e}-5$, and an output was produced [39]. The Blast search outputs and the positions of all protein-coding genes were imported into MCScanX software (http://chibba.pgml.uga.edu/mcscan2/), and the genes were classified into the various types of duplications, including segmental, tandem, proximal, and dispersed duplications [40], using the default parameters [41]. Synteny relationships were visualized with CIRCOS software [42]. Non-synonymous (Ka) and synonymous (Ks) substitution rates and the $\mathrm{Ka} / \mathrm{Ks}$ ratio were estimated using DnaSP v5 software [43].

\section{Expression analysis of the GhIQD genes}

In the present study, RNA-seq data was downloaded from the public Cotton Functional Genomics Database (CottonFGD, https://cottonfgd.org/about/download.html), and the data were then used to 
survey the expression of the GhIQD genes [44]. The accession numbers of the RNA-Seq data for $5 \mathrm{dpa}, 10$ dpa, 20 dpa, and 25 dpa are SRR1695191, SRR1695192, SRR1695193, and SRR1695194, respectively, and all the expression values were standardized to fragments per kilobase per million (FPKM) values [45]. The heatmap was peformed to visualize gene expression patterns using OmicShare tools (https://www.omicshare.com/tools/Home/Soft/heatmap). R software was used to visualize the gene expression profiles, and the TCseq package [46] was used to cluster the GhIQD gene expression patterns.

\section{Plant materials and treatments}

The G. hirsutum L. cultivar TM-1 was grown in the field in Anyang, Henan province, China. Leaves, stems, roots, and hypocotyl tissues were collected at the seedling stage. Stigma, petal, pollen, and calyx samples were collected at the flowering stage. The G. hirsutum L. cultivar Shiyuan 321 was grown in a greenhouse under a $14 \mathrm{~h}$ light / $10 \mathrm{~h}$ dark photoperiod at $30^{\circ} \mathrm{C}$ (day) and at $28^{\circ} \mathrm{C}$ (night) [47]. Seedlings at the five-leaf stage were sprayed with $0.5 \mathrm{mM}$ MeJA and sampled at seven time points $(0 \mathrm{~h}, 3 \mathrm{~h}, 6 \mathrm{~h}, 12 \mathrm{~h}, 24 \mathrm{~h}, 48 \mathrm{~h}$, and $72 \mathrm{~h}$ ) after treatment [48].

The cotton cultivars TM-1 and Shiyuan 321 were obtained from the State Key Laboratory of Cotton Biology, Institute of Cotton Research of Chinese Academy of Agricultural Sciences. All tissue samples were immediately frozen in liquid nitrogen and stored at $-80^{\circ} \mathrm{C}$, and three biological replicates were conducted for each sample.

\section{RNA extraction and quantitative real-time PCR (qRT-PCR) analysis}

Total RNA from the collected samples was extracted using the Tiangen RNAprep Pure Plant Plus Kit (cat. no. DP441; Tiangen, Beijing, China) as directed by the manufacturer. First-strand cDNA was synthesized via reverse transcription of $2 \mu \mathrm{g}$ of total RNA using the PrimeScript ${ }^{\mathrm{TM}}$ RT reagent Kit with gDNA Eraser (cat. no. RR047A; TaKaRa, Shiga, Japan). Oligo 7 software was used to design gene-specific primers for qRT-PCR (Additional file 5). The GhHis3 gene (AF024716) was used as an internal reference control for gene expression [49]. The qRT-PCR experiments were performed with the TB Green ${ }^{\mathrm{TM}}$ Premix Ex Taq ${ }^{\mathrm{TM}}$ II RNaseH Plus kit (cat. no. RR420A; TaKaRa, Shiga, Japan) on an ABI7500 real-time PCR system (Applied Biosystems, USA) with three replicates per sample. qRT-PCR assays were performed in a volume of $20 \mu \mathrm{l}$, which contained $2 \mu \mathrm{l}$ of each primer, $1 \mu \mathrm{l}$ of cDNA and $7 \mu \mathrm{l}$ of $\mathrm{dd}_{2} \mathrm{O}$. The amplification conditions were as follows: initial denaturation at $95^{\circ} \mathrm{C}$ for 2 min (Step 1), followed by 40 cycles of $10 \mathrm{~s}$ at $95^{\circ} \mathrm{C}, 15 \mathrm{~s}$ at $58^{\circ} \mathrm{C}$, and $15 \mathrm{~s}$ at $72^{\circ} \mathrm{C}$ (Step 2). The relative expression levels of the GhIQD genes were calculated using the $2^{-\triangle \triangle C T}$ method [50]. Statistical analyses were conducted using the t-test as implemented in SPSS software [51].

\section{Abbreviations}

CaM, Calmodulin; CML, CaM-like; CBL, calcineurin B-like; CDPK, calcium-dependent protein kinases; ApoCaM, apocalmodulin; CAMTA, calmodulin-binding transcription activator; CNGC, nucleotide-gated channel; IQD, IQ domain; IQM, IQ-motif; CaMBP, CaM/CML -binding protein, ABA, abscisic acid; KLCR, 
kinesin light chain-related; MeJA, methyl jasmonate; aa, amino acid; bp, base pair; Da, Dalton; ER, endoplasmic reticulum; NJ, Neighbor-Joining; Ks, synonymous; Ka, non-synonymous; dpa, days post anthesis; CottonFGD, Cotton Functional Genomics Database; TAIR, Arabidopsis Information Resource; HMM, Hidden Markov Model; pl, isoelectric point; MW, molecular weight; FPKM, fragments per kilobase per million.

\section{Declarations}

\section{Acknowledgements}

The authors thank the State Key Laboratory of Cotton Biology, Institute of Cotton Research of Chinese Academy of Agricultural Sciences for providing experimental support.

\section{Authors' contributions}

Formal analysis, RMX and CSZ; Investigation, QZ. Resources, HZL; Software, CYP and YHL; Visualization, LLM and WWB; Writing original draft, LLD; Review and editing, GLS and GHX.

\section{Funding}

This research was sponsored by the State Key Laboratory of Cotton Biology Open Fund (grant numbers CB2019A03 and CB2018A07), the National Natural Science Foundation of China (grant number 31872175), and Key Research and Development Program of Shaanxi Province (grant number 2019NY103). The funding bodies provided the financial support to the research projects, but didn't involved in study design, data collection, analysis, or preparation of the manuscript.

\section{Availability of data and materials}

All data generated or analyzed during this study are included in this published article and its additional files.

\section{Ethics declarations}

\section{Ethics approval and consent to participate}

Not applicable

\section{Consent for publication}

Not applicable.

\section{Competing interests}

The authors declare that they have no competing of interests. 
Author details

${ }^{1}$ School of Chemistry and Chemical Engineering, Xianyang Normal University, Xianyang 712000, Shaanxi, China

${ }^{2}$ State Key Laboratory of Cotton Biology, Institute of Cotton Research of Chinese Academy of Agricultural Sciences, Anyang 455000, China

${ }^{3}$ Zhengzhou University research base for State Key Laboratory of Cotton Biology in China

${ }^{4}$ Key Laboratory of Plant Stress Biology, State Key Laboratory of Cotton Biology, School of Life Sciences, Henan University, Kaifeng, China.

${ }^{5}$ College of Life Sciences, Shaanxi Normal University, Xi'an 710119, China;

${ }^{6}$ Zhengzhou Research Base, State Key Laboratory of Cotton Biology, Zhengzhou University, Zhengzhou, China

\section{References}

1. Reddy AS, Ali GS, Celesnik H, Day IS: Coping with stresses: roles of calcium- and calcium/calmodulin-regulated gene expression. The Plant cell 2011, 23(6):2010-2032.

2. Liu T, Zhuang L, Huang B: Metabolic adjustment and gene expression for root sodium transport and calcium signaling contribute to salt tolerance in Agrostis grass species. Plant and Soil 2019(1-10):114.

3. Yuan P, Jauregui E, Du L, Tanaka K, Poovaiah BW: Calcium signatures and signaling events orchestrate plant-microbe interactions. Current Opinion in Plant Biology 2017, 38:173-183.

4. Yuan P, Jauregui E, Du L, Tanaka K, Poovaiah B: Calcium signatures and signaling events orchestrate plant-microbe interactions. Current Opinion in Plant Biology 2017, 38:173-183.

5. Salveson I, Anderson DE, Hell JW, Ames JB: Chemical shift assignments of a calmodulin intermediate with two $\mathrm{Ca}^{2+}$ bound in complex with the IQ-motif of voltage-gated $\mathrm{Ca}^{2+}$ channels (CaV1.2). Biomolecular NMR Assignments 2019, 13(1):233.

6. Hernandez Sebastia C, Hardin SC, Clouse SD, Kieber JJ, Huber SC: Identification of a new motif for CDPK phosphorylation in vitro that suggests ACC synthase may be a CDPK substrate. Archives of biochemistry and biophysics 2004, 428(1):81-91.

7. Wei CC, Fabry E, Hay E, Lloyd L, Kaufman N, Yang YP, Stuehr DJ: Metal binding and conformational studies of the calcium binding domain of NADPH oxidase 5 reveal its similarity and difference to calmodulin. Journal of biomolecular Structure \& Dynamics 2019(5):1-29.

8. Ma H, Feng L, Chen Z, Chen X, Zhao H, Xiang Y: Genome-wide identification and expression analysis of the IQD gene family in Populus trichocarpa. Plant science : an international journal of 
experimental plant biology 2014, 229:96-110.

9. Zhang X, Zhou H, Zang X, Gong L, Sun H, Zhang X: MIPS: a calmodulin-binding protein of Gracilaria lemaneiformis under heat shock. Marine biotechnology 2014, 16(4):475-483.

10. Bahler M, Rhoads A: Calmodulin signaling via the IQ motif. FEBS letters 2002, 513(1):107-113.

11. Feldkamp MD, Yu L, Shea MA: Structural and energetic determinants of apo calmodulin binding to the IQ motif of the $\mathrm{Na}(\mathrm{V}) 1.2$ voltage-dependent sodium channel. Structure 2011, 19(5):733-747.

12. Nakanishi A, Hatano N, Fujiwara Y, Bin SA, Takabatake S, Akano H, Kanayama N, Magari M, Nozaki $\mathrm{N}$, Tokumitsu H: AMP-activated protein kinase-mediated feedback phosphorylation controls the $\mathrm{Ca}(2+)$ /calmodulin (CaM) dependence of $\mathrm{Ca}(2+) / \mathrm{CaM}$-dependent protein kinase kinase $\beta$. Journal of Biological Chemistry 2017, 292:jbc.M117.805085.

13. Zhou YP, Wu JH, Xiao WH, Chen W, Chen QH, Fan T, Xie CP, Tian CE: Arabidopsis IQM4, a Novel Calmodulin-Binding Protein, Is Involved With Seed Dormancy and Germination in Arabidopsis. Frontiers in plant science 2018, 9:721.

14. DeFalco TA, Bender KW, Snedden WA: Breaking the code: $\mathrm{Ca}^{2+}$ sensors in plant signalling. The Biochemical journal 2009, 425(1):27-40.

15. Steffen A, Katharina B, Jens M: The emerging function of IQD proteins as scaffolds in cellular signaling and trafficking. Plant Signaling \& Behavior 2013, 8(6):-.

16. Abel S, Savchenko T, Levy M: Genome-wide comparative analysis of the IQD gene families in Arabidopsis thaliana and Oryza sativa. BMC evolutionary biology 2005, 5:72.

17. Burstenbinder K, Savchenko T, Muller J, Adamson AW, Stamm G, Kwong R, Zipp BJ, Dinesh DC, Abel S: Arabidopsis calmodulin-binding protein IQ67-domain 1 localizes to microtubules and interacts with kinesin light chain-related protein-1. The Journal of biological chemistry 2013, 288(3):18711882.

18. Wu M, Li Y, Chen D, Liu H, Zhu D, Xiang Y: Genome-wide identification and expression analysis of the IQD gene family in moso bamboo (Phyllostachys edulis). Sci Rep 2016, 6:24520.

19. Feng L, Chen Z, Ma H, Chen X, Li Y, Wang Y, Xiang Y: The IQD gene family in soybean: structure, phylogeny, evolution and expression. PLoS One 2014, 9(10):e110896.

20. Huang Z, Van Houten J, Gonzalez G, Xiao H, van der Knaap E: Genome-wide identification, phylogeny and expression analysis of SUN, OFP and YABBY gene family in tomato. Molecular genetics and genomics : $M G G$ 2013, 288(3-4):111-129.

21. Liang H, Yi Z, Pablo M, Carolyn R, Tongda X, Zhenbiao Y: The microtubule-associated protein IQ67 DOMAIN5 modulates microtubule dynamics and pavement cell shape. Plant Physiology 2018, 177:1555-1568.

22. Bi L, Lin W, Zhuyan J, Han X: The tomato IQD gene SUN24 regulates seed germination through ABA signaling pathway. Planta 2018, 248:919-931.

23. Li J, Wu Y, Zhang Q, Li H, Pan H, Lu W, Wang D, Zhang J, Lu Y: Aphid parasitism and parasitoid diversity in cotton fields in Xinjiang, China. PLoS One 2018, 13(11):e0207034. 
24. Shaban M, Ahmed MM, Sun H, Ullah A, Zhu L: Genome-wide identification of lipoxygenase gene family in cotton and functional characterization in response to abiotic stresses. BMC genomics 2018, 19(1):599.

25. Wang M, Tu L, Yuan D, Zhu, Shen C, Li J, Liu F, Pei L, Wang P, Zhao G et al: Reference genome sequences of two cultivated allotetraploid cottons, Gossypium hirsutum and Gossypium barbadense. Nature genetics 2019, 51(2):224-229.

26. Cunwu Z, Yulian L, Zhigang G, Juan M, Mingyu C, Baihong C: Genome-wide annotation and expression responses to biotic stresses of the WALL-ASSOCIATED KINASE - RECEPTOR-LIKE KINASE (WAK-RLK) gene family in Apple (Malus domestica). European Journal of Plant Pathology 2018, 8:115.

27. Verma G, Dhar YV, Srivastava D, Kidwai M, Chauhan PS, Bag SK, Asif MH, Chakrabarty D: Genomewide analysis of rice dehydrin gene family: Its evolutionary conservedness and expression pattern in response to PEG induced dehydration stress. PLoS One 2017, 12(5):e0176399.

28. Bürstenbinder K, Möller B, Plötner R, Stamm G, Hause G, Mitra D, Abel S: The IQD Family of Calmodulin-Binding Proteins Links Calcium Signaling to Microtubules, Membrane Subdomains, and the Nucleus. Plant Physiology 2017, 173(3):pp.01743.02016.

29. Hu G, Koh J, Yoo MJ, Grupp K, Chen S, Wendel JF: Proteomic profiling of developing cotton fibers from wild and domesticated Gossypium barbadense. The New phytologist 2013, 200(2):570-582.

30. Badmi R, Payyavula RS, Bali G, Guo HB, Jawdy SS, Gunter LE, Yang X, Winkeler KA, Collins C, Rottmann WH et al: A New Calmodulin-Binding Protein Expresses in the Context of Secondary Cell Wall Biosynthesis and Impacts Biomass Properties in Populus. Frontiers in plant science 2018, 9:1669.

31. Bürstenbinder K, Mitra D, Quegwer J: Functions of IQD proteins as hubs in cellular calcium and auxin signaling: A toolbox for shape formation and tissue-specification in plants? Plant Signaling \& Behavior 2017, 12(6):1692-1708.

32. Yan C, Fan M, Yang M, Zhao J, Zhang W, Su Y, Xiao L, Deng H, Xie D: Injury Activates Ca 2+ /Calmodulin-Dependent Phosphorylation of JAV1-JAZ8-WRKY51 Complex for Jasmonate Biosynthesis. Molecular Cell 2018, 70(1):136-149.e137.

33. Pei Y: Role of hydrogen sulfide in the methyl jasmonate response to cadmium stress in foxtail millet. Front Biosci 2017, 22(3):530-538.

34. Lin F, Zhu C, Hui M, Xue C, Yuan L, Yiyi W, Yan X: The IQD gene family in soybean: structure, phylogeny, evolution and expression. Plos One 2014, 9(10):e110896.

35. Voorrips RE: MapChart: software for the graphical presentation of linkage maps and QTLs. The Journal of heredity 2002, 93(1):77-78.

36. Kumar S, Stecher G, Tamura K: MEGA7: Molecular Evolutionary Genetics Analysis version 7.0 for bigger datasets. Molecular Biology \& Evolution 2016, 33(7):1870.

37. Qin L, Mo N, Muhammad T, Liang Y: Genome-Wide Analysis of DCL, AGO, and RDR Gene Families in Pepper (Capsicum Annuum L.). International Journal of Molecular Sciences 2018, 19(4):1038. 
38. Yupeng W, Haibao T, Debarry JD, Xu T, Jingping L, Xiyin W, Tae-Ho L, Huizhe J, Barry M, Hui G: MCScanX: a toolkit for detection and evolutionary analysis of gene synteny and collinearity. Nucleic Acids Research 2012, 40(7):e49-e49.

39. Knip M: The SLEEPER genes: a transposase-derived angiosperm-specific gene family. Bmc Plant Biology 2012, 12(1):192.

40. Jia Y, Li B, Zhang Y, Zhang X, Xu Y, Li C: Evolutionary dynamic analyses on monocot flavonoid 3'hydroxylase gene family reveal evidence of plant-environment interaction. BMC Plant Bio/2019, 19(1):347.

41. You J, Zhang L, Song B, Qi X, Chan Z: Systematic analysis and identification of stress-responsive genes of the NAC gene family in Brachypodium distachyon. PLoS One 2015, 10(3):e0122027.

42. Krzywinski M, Schein J, Birol I, Connors J, Gascoyne R, Horsman D, Jones SJ, Marra MA: Circos: an information aesthetic for comparative genomics. Genome research 2009, 19(9):1639-1645.

43. Librado P, Rozas J: DnaSP v5: a software for comprehensive analysis of DNA polymorphism data. Bioinformatics 2009, 25(11):1451-1452.

44. Zhu T, Liang C, Meng Z, Sun G, Meng Z, Guo S, Zhang R: CottonFGD: an integrated functional genomics database for cotton. BMC Plant Biol 2017, 17(1):101.

45. Dong C, Wang J, Yu Y, Ju L, Zhou X, Ma X, Mei G, Han Z, Si Z, Li B et al: Identifying Functional Genes Influencing Gossypium hirsutum Fiber Quality. Frontiers in plant science 2018, 9:1968.

46. Feng S, Xu M, Liu F, Cui C, Zhou B: Reconstruction of the full-length transcriptome atlas using PacBio Iso-Seq provides insight into the alternative splicing in Gossypium australe. BMC Plant Bio/ 2019, 19(1):365.

47. Wang L, Yang Z, Zhang B, Yu D, Liu J, Gong Q, Qanmber G, Li Y, Lu L, Lin Y et al: Genome-wide characterization and phylogenetic analysis of GSK gene family in three species of cotton: evidence for a role of some GSKs in fiber development and responses to stress. BMC Plant Bio/2018, 18(1):330.

48. Yang Y, Chen T, Ling X, Ma Z: Gbvdr6, a Gene Encoding a Receptor-Like Protein of Cotton (Gossypium barbadense), Confers Resistance to Verticillium Wilt in Arabidopsis and Upland Cotton. Frontiers in plant science $2017,8: 2272$.

49. Wang $M$, Wang $Q$, Zhang $B$ : Evaluation and selection of reliable reference genes for gene expression under abiotic stress in cotton (Gossypium hirsutum L.). Gene 2013, 530(1):44-50.

50. Livak KJ, Schmittgen TD: Analysis of relative gene expression data using real-time quantitative PCR and the 2(-Delta Delta C(T)) Method. Methods 2001, 25(4):402-408.

51. Sun H, Hao P, Ma Q, Zhang M, Qin Y, Wei H, Su J, Wang H, Gu L, Wang N et al: Genome-wide identification and expression analyses of the pectate lyase (PEL) gene family in cotton (Gossypium hirsutum L.). BMC genomics 2018, 19(1):661.

\section{Table}




\section{Sample characteristics}

Among the participants, $88.1 \%$ were male, $54.5 \%$ were over 45 years old, $84.2 \%$ had more than a highschool education, $45.5 \%$ worked in manufacturing, $54.5 \%$ were craft or machine operator and assemblers, $65.3 \%$ were regular workers, and $70.3 \%$ worked in small- or medium-sized organizations. Fractures represented the largest portion (61.4\%) of primary injuries, followed by cartilage or tendon rupture (23.8\%). More than half of the participants had injured their lower extremities (47.5\%), spine (45.0\%), or upper extremities (30.7\%) (table 1).

As shown in Table 2, the mean scores of each item of the RTWSE-19 ranged from $4.72 \pm 3.38$ to 8.09 \pm 2.39 . The two items with the highest mean scores were item 16 ("Could you describe to your supervisor the nature of your injury and your medical treatment") and item 17 ("Could you discuss openly with your supervisor things that may contribute to your discomfort") with mean scores of $8.09 \pm 2.39$ and $7.97 \pm 2.48$, respectively. The two items with the lowest mean scores were item 3 ("Could you change the type of work activities you do to reduce discomfort") and item 14 ("Could you reduce your physical workload") with mean scores of $4.72 \pm 3.38$ and $4.81 \pm 3.13$, respectively. Items related to the "communicating needs to others" subscale showed relatively higher mean scores, while items related to the "modifying job tasks" subscale featured relatively lower mean scores.

\section{Evaluation of psychometric properties}

Exploratory Factor Analysis. EFA models of 1-4 factors revealed that a 3-factor model was the best fit for the 19-item scale $(=228.834, \mathrm{p}<.000 ; \mathrm{CFI}=.953 ; \mathrm{TLI}=.931$; RMSEA $=.069 ; \mathrm{SRMR}=0.032)$, but low factor loading (below 0.4)was indicated for item 1 ("Could you suggest to your supervisor ways to change your work to reduce discomfort?") and item 7 ("Could you avoid re-injury?").

After removing two items from the item pool, EFA was conducted for 1 
Table 1. Information of GhIQD gene family members in G.hirsutum L. ,their sequence characteristics and subcellular location .

\begin{tabular}{|c|c|c|c|c|c|c|c|}
\hline Gene ID & Gene name & $\begin{array}{l}\text { length } \\
\text { (aa) }\end{array}$ & $\begin{array}{l}\text { ORF } \\
\text { length } \\
\text { (bp) }\end{array}$ & $\begin{array}{l}\text { Mass } \\
\text { (Da) }\end{array}$ & $\mathrm{pl}$ & $\begin{array}{l}\text { Predicted } \\
\text { location }\end{array}$ & $\begin{array}{l}\text { Exon } \\
\text { number }\end{array}$ \\
\hline GH_A01G1101 & GhIQDA01.2 & 838 & 2517 & 92762.8 & 6.45 & nucl & 6 \\
\hline GH_A01G2332 & GhIQDA01.3 & 466 & 1401 & 51680.07 & 10.04 & nucl & 5 \\
\hline GH_A02G0100 & GhIQDA02.1 & 540 & 1623 & 60671.48 & 11.13 & nucl & 5 \\
\hline GH_A02G1393 & GhIQDA02.2 & 385 & 1158 & 43210.99 & 10.19 & nucl & 3 \\
\hline GH_A04G0950 & GhIQDA04.1 & 467 & 1404 & 51973.41 & 10.46 & nucl & 5 \\
\hline GH_A05G0263 & GhIQDA05.1 & 411 & 1236 & 45861.25 & 10.34 & nucl & 3 \\
\hline GH_A05G0790 & GhIQDA05.2 & 434 & 1305 & 47787.02 & 9.98 & nucl & 6 \\
\hline GH_A05G1339 & GhIQDA05.3 & 403 & 1212 & 44740.05 & 10.14 & nucl & 3 \\
\hline GH_A05G1378 & GhIQDA05.4 & 447 & 1344 & 50742.09 & 10.1 & nucl & 4 \\
\hline GH_A05G1577 & GhIQDA05.5 & 306 & 921 & 34962.1 & 10.42 & nucl & 5 \\
\hline GH_A05G1877 & GhIQDA05.6 & 900 & 2703 & 99312.5 & 5.27 & nucl & 6 \\
\hline GH_A05G3022 & GhIQDA05.7 & 339 & 1020 & 37749.85 & 10.8 & nucl & 4 \\
\hline GH_A05G3607 & GhIQDA05.8 & 574 & 1725 & 52858.66 & 10.51 & nucl & 5 \\
\hline GH_A05G4277 & GhIQDA05.9 & 464 & 1395 & 52514.35 & 10.14 & nucl & 5 \\
\hline GH_A06G0050 & GhIQDA06.1 & 659 & 1980 & 72053.71 & 6.26 & nucl & 5 \\
\hline GH_A06G1837 & GhIQDA06.2 & 442 & 1329 & 50167.53 & 9.86 & nucl & 5 \\
\hline GH_A06G1940 & GhIQDA06.3 & 382 & 1149 & 43725.98 & 10.81 & nucl & 5 \\
\hline GH_A07G0094 & GhIQDA07.1 & 414 & 1245 & 45320.56 & 10.21 & nucl & 3 \\
\hline GH_A07G0227 & GhIQDA07.2 & 437 & 1314 & 49258.14 & 10.51 & nucl & 5 \\
\hline GH_A07G0720 & GhIQDA07.3 & 651 & 1956 & 72594.59 & 9.72 & nucl & 6 \\
\hline GH_A08G1336 & GhIQDA08.2 & 539 & 1620 & 60952.52 & 9.78 & nucl & 4 \\
\hline GH_A08G2765 & GhIQDA08.4 & 360 & 1083 & 39811.23 & 10.4 & nucl & 3 \\
\hline GH_A08G2816 & GhIQDA08.5 & 418 & 1257 & 47014.72 & 10.52 & nucl & 5 \\
\hline GH_A09G1366 & GhIQDA09.2 & 409 & 1230 & 46558.51 & 10.2 & nucl & 5 \\
\hline GH_A09G1685 & GhIQDA09.3 & 452 & 1359 & 50179.15 & 10.12 & nucl & 5 \\
\hline GH_A09G2303 & GhIQDA09.5 & 511 & $\begin{array}{l}1536 \\
\text { Page 17/28 }\end{array}$ & 56997.69 & 11.39 & nucl & 5 \\
\hline
\end{tabular}




\begin{tabular}{|c|c|c|c|c|c|c|c|}
\hline GH_A09G2394 & GhIQDA09.6 & 404 & 1215 & 45045.51 & 9.94 & nucl & 3 \\
\hline GH_A10G0319 & GhIQDA10.1 & 311 & 936 & 35184.76 & 10.9 & nucl & 5 \\
\hline GH_A10G1560 & GhIQDA10.2 & 523 & 1572 & 58681.88 & 10.66 & nucl & 5 \\
\hline GH_A11G0174 & GhIQDA11.1 & 293 & 882 & 33829.1 & 11.24 & nucl & 3 \\
\hline GH_A11G0321 & GhIQDA11.2 & 767 & 2304 & 84830.18 & 9.77 & nucl & 6 \\
\hline GH_A11G1049 & GhIQDA11.3 & 531 & 1596 & 59599.5 & 10.51 & nucl & 5 \\
\hline GH_A11G1587 & GhIQDA11.4 & 381 & 1146 & 43192.29 & 9.28 & nucl & 6 \\
\hline GH_A12G1325 & GhIQDA12.1 & 500 & 1503 & 55878.89 & 10.73 & nucl & 5 \\
\hline GH_A12G2604 & GhIQDA12.2 & 519 & 1560 & 59126.62 & 9.88 & nucl & 5 \\
\hline GH_A12G2690 & GhIQDA12.3 & 451 & 1356 & 49874.94 & 9.74 & nucl & 4 \\
\hline GH_A13G0768 & GhIQDA13.2 & 549 & 1650 & 60060.1 & 9.99 & nucl & 6 \\
\hline GH_A13G0771 & GhIQDA13.3 & 550 & 1653 & 60669.01 & 10 & nucl & 6 \\
\hline GH_A13G1240 & GhIQDA13.5 & 306 & 921 & 34548.98 & 10.4 & nucl & 3 \\
\hline GH_A13G1987 & GhIQDA13.6 & 362 & 1089 & 41511.44 & 10.45 & nucl & 3 \\
\hline GH_A13G2167 & GhIQDA13.7 & 326 & 981 & 38128.29 & 10.38 & nucl & 5 \\
\hline GH_D01G1150 & GhIQDD01.2 & 838 & 2517 & 92819.9 & 6.13 & nucl & 6 \\
\hline GH_D01G2410 & GhIQDD01.3 & 466 & 1401 & 51732.91 & 10.07 & nucl & 5 \\
\hline GH_D02G0104 & GhIQDD02.1 & 543 & 1632 & 61081.99 & 11.09 & nucl & 5 \\
\hline GH_D03G0607 & GhIQDD03.2 & 385 & 1158 & 43307.07 & 10.25 & nucl & 3 \\
\hline GH_D04G0099 & GhIQDD04.1 & 464 & 1395 & 52501.4 & 10.16 & nucl & 5 \\
\hline GH_D04G0861 & GhIQDD04.2 & 474 & 1425 & 52953.74 & 10.51 & nucl & 5 \\
\hline GH_D04G1282 & GhIQDD04.3 & 470 & 1413 & 52267.63 & 10.25 & nucl & 5 \\
\hline GH_D05G0268 & GhIQDD05.1 & 411 & 1236 & 45920.33 & 10.28 & nucl & 3 \\
\hline GH_D05G0787 & GhIQDD05.2 & 435 & 1308 & 48163.42 & 10.09 & nucl & 6 \\
\hline GH_D05G1342 & GhIQDD05.3 & 403 & 1212 & 44653.93 & 10.36 & nucl & 3 \\
\hline GH_D05G1385 & GhIQDD05.4 & 447 & 1344 & 50640.2 & 10.09 & nucl & 4 \\
\hline GH_D05G1607 & GhIQDD05.5 & 306 & 921 & 34947.05 & 10.39 & nucl & 5 \\
\hline GH_D05G1915 & GhIQDD05.6 & 900 & 2703 & 99360.68 & 5.3 & nucl & 6 \\
\hline GH_D05G3028 & GhIQDD05.7 & 427 & 1284 & 47736.21 & 10.29 & nucl & 5 \\
\hline
\end{tabular}




\begin{tabular}{|c|c|c|c|c|c|c|c|}
\hline GH_D06G0037 & GhIQDD06.1 & 664 & 1995 & 72524.53 & 6.89 & nucl & 5 \\
\hline GH_D06G1866 & GhIQDD06.2 & 442 & 1329 & 50104.22 & 9.81 & nucl & 5 \\
\hline GH_D06G1971 & GhIQDD06.3 & 386 & 1161 & 44138.29 & 10.65 & nucl & 5 \\
\hline GH_D07G0100 & GhIQDD07.1 & 415 & 1248 & 45440.73 & 10.2 & nucl & 3 \\
\hline GH_D07G0234 & GhIQDD07.2 & 437 & 1314 & 49274.22 & 10.48 & nucl & 5 \\
\hline GH_D07G0707 & GhIQDD07.3 & 650 & 1953 & 72097.97 & 9.75 & nucl & 6 \\
\hline GH_D08G1206 & GhIQDD08.3 & 540 & 1623 & 60919.52 & 9.78 & nucl & 4 \\
\hline GH_D08G2761 & GhIQDD08.5 & 359 & 1080 & 39873.37 & 10.43 & nucl & 3 \\
\hline GH_D08G2809 & GhIQDD08.6 & 395 & 1188 & 44794.15 & 10.56 & nucl & 5 \\
\hline GH_D09G1141 & GhIQDD09.1 & 436 & 1311 & 47553.9 & 10.08 & nucl & 6 \\
\hline GH_D09G1315 & GhIQDD09.2 & 414 & 1245 & 47099.05 & 10.12 & nucl & 5 \\
\hline GH_D09G1630 & GhIQDD09.3 & 446 & 1341 & 49661.4 & 10.1 & nucl & 5 \\
\hline GH_D09G2241 & GhIQDD09.4 & 511 & 1536 & 57044.68 & 11.27 & nucl & 5 \\
\hline GH_D09G2334 & GhIQDD09.5 & 406 & 1221 & 45218.73 & 9.98 & nucl & 3 \\
\hline GH_D10G0332 & GhIQDD10.1 & 311 & 936 & 35020.59 & 10.74 & nucl & 5 \\
\hline GH_D10G1333 & GhIQDD10.2 & 523 & 1572 & 58604.9 & 10.63 & nucl & 5 \\
\hline GH_D11G0175 & GhIQDD11.1 & 293 & 882 & 33561.81 & 11.06 & nucl & 3 \\
\hline GH_D11G0334 & GhIQDD11.2 & 767 & 2304 & 84784.04 & 9.8 & nucl & 6 \\
\hline GH_D11G1078 & GhIQDD11.3 & 531 & 1596 & 59590.38 & 10.55 & nucl & 5 \\
\hline GH_D11G1617 & GhIQDD11.4 & 411 & 1236 & 47034.9 & 9.46 & nucl & 7 \\
\hline GH_D12G1345 & GhIQDD12.1 & 501 & 1506 & 56136.15 & 10.76 & nucl & 5 \\
\hline GH_D12G2626 & GhIQDD12.3 & 518 & 1557 & 58961.41 & 9.89 & nucl & 5 \\
\hline GH_D12G2716 & GhIQDD12.4 & 451 & 1356 & 49960.99 & 9.73 & nucl & 4 \\
\hline GH_D13G0741 & GhIQDD13.2 & 522 & 1569 & 60358.36 & 9.98 & nucl & 6 \\
\hline GH_D13G0744 & GhIQDD13.3 & 552 & 1659 & 60897.05 & 9.98 & nucl & 6 \\
\hline GH_D13G1947 & GhIQDD13.5 & 376 & 1131 & 43085.2 & 10.43 & nucl & 3 \\
\hline GH_D13G2149 & GhIQDD13.6 & 377 & 1134 & 42426.34 & 10.51 & nucl & 5 \\
\hline GH_A01G0547 & GhIQDA01.1 & 285 & 858 & 32302.82 & 10.15 & mito & 5 \\
\hline GH_A02G2016 & GhIQDA02.3 & 120 & 363 & 13689.84 & 11.79 & mito & 3 \\
\hline
\end{tabular}




\begin{tabular}{cccccccc} 
GH_A03G0236 & GhIQDA03.1 & 488 & 1467 & 53976.96 & 9.96 & mito & 4 \\
\hline GH_A13G0956 & GhIQDA13.4 & 480 & 1443 & 53068.34 & 9.98 & mito & 5 \\
\hline GH_D01G0541 & GhIQDD01.1 & 285 & 858 & 32287.85 & 10.11 & mito & 5 \\
\hline GH_D03G0046 & GhIQDD03.1 & 133 & 402 & 15440.04 & 11.65 & mito & 2 \\
\hline GH_D03G1733 & GhIQDD03.3 & 489 & 1470 & 54209.22 & 10.02 & mito & 4 \\
\hline GH_D12G2109 & GhIQDD12.2 & 315 & 948 & 36162.76 & 10.74 & mito & 4 \\
\hline GH_D13G1022 & GhIQDD13.4 & 480 & 1443 & 52890.99 & 9.94 & mito & 5 \\
\hline GH_A08G1119 & GhIQDA08.1 & 445 & 1338 & 49676.63 & 9.38 & E.R. & 4 \\
\hline GH_D08G1102 & GhIQDD08.1 & 445 & 1338 & 49457.39 & 9.38 & E.R. & 4 \\
\hline GH_A09G1181 & GhIQDA09.1 & 436 & 1311 & 47752.06 & 10 & chlo & 6 \\
\hline GH_A08G2051 & GhIQDA08.3 & 317 & 954 & 35369.75 & 10.06 & chlo & 4 \\
\hline GH_A09G1949 & GhIQDA09.4 & 461 & 1386 & 51179.31 & 10.33 & chlo & 4 \\
\hline GH_A10G2676 & GhIQDA10.3 & 384 & 1155 & 43186.39 & 9.93 & chlo & 4 \\
\hline GH_A13G0121 & GhIQDA13.1 & 385 & 1158 & 44219.64 & 10.37 & chlo & 5 \\
\hline GH_D08G1176 & GhIQDD08.2 & 456 & 1371 & 50866.22 & 10.21 & chlo & 4 \\
\hline GH_D08G2064 & GhIQDD08.4 & 508 & 1527 & 56482.43 & 9.83 & chlo & 6 \\
\hline GH_D10G2782 & GhIQDD10.3 & 398 & 1197 & 45120.65 & 9.88 & chlo & 4 \\
\hline GH_D13G0120 & GhIQDD13.1 & 385 & 1158 & 44188.66 & 10.27 & chlo & 5 \\
\hline
\end{tabular}

Note: nucl, indicates nucleus; mito, indicates mitochondria; chlo, indicates chloroplast; E.R. indicates endoplasmic reticulum;

-4 factor models. The 3-factor model of the 17 item-scale demonstrated reasonable model fit, with marginal improvement of fit-index values $(=169.401, \mathrm{p}<.000 ; \mathrm{CFI}=.963 ; \mathrm{TLI}=.943 ; \mathrm{RMSEA}=.068$; SRMR $=0.029)$ compared to 3 -factor model of the 19-item scale. The resulting screen test also suggested a 3 -factor solution. The final model revealed three distinct concepts: meeting job demands (7 items), modifying job tasks (5 items), and communicating needs to others (5 items). Two items from the original 19-item scale which concerned modifying job tasks were excluded from the final model. The factor loadings for each item are presented in Table 2.

Intercorrelations of subscales. Subscales were significantly and moderately correlated: meeting job demands and modifying job tasks $(r=0.612, p<.001)$; meeting job demands and communicating needs 
$(r=0.494, p<.001)$; and modifying job tasks and communicating needs $(r=0.501, p<.001)$ (table 3$)$.

Floor and ceiling effect. No floor or ceiling effects were found for total RTWSE and subscale scores using the criteria of $15 \%$. Regarding communicating needs RTWSE, $12.4 \%$ achieved the highest score (10), below the 15\% cutoff (table 3 ).

Reliability. All Cronbach's alphas for the overall scale and subscales were satisfactory. The Cronbach's alpha for the overall RTWSE-17 was 0.925 and was 0.842 for communicating needs, 0.851 for modifying job tasks, and 0.926 for meeting job demands (table 3 ).

\section{Construct validity}

Significant correlations were found between fear-avoidance beliefs about physical activity $(r=-0.231, p<$ $0.001)$ and work $(r=-0.441, p<0.001)$, SF-12 mental health $(r=0.324, p<0.001)$, depression $(r=-0.301$, $p<0.001)$, and general self-efficacy $(r=0.502, p<0.001)$ and RTWSE-17 scores. Current pain intensity ( $r=$ $-0.028, p=.692)$ and SF-12 physical health $(r=0.061, p=.386)$ showed no correlation, and the monthly average pain intensity $(r=-0.150, p=0.033)$ showed low correlation with RTWSE-17 scores. These patterns did not differ in significance or direction when applied to the subscales of the RTWSE-17, except that physical fear-avoidance showed no correlation with modifying job tasks and communicating needs (table 4).

\section{Additional File Legends}

Additional file 1: Predicted calmodulin-binding sites of IQD proteins in G. hirsutum L. The calmodulinbinding sites were predicted with the online Calmodulin Target Database software, and the table shows strings of amino acid residues with a score of at least 7. Residues with a score of 9 are highlighted in bold. The numbers before the strings and after the strings indicate the locations of the first and the last amino acid residues of the strings in the GhIQD protein, respectively.

Additional file 2: List of segmentally duplicated IQD gene pairs in the G. hirsutum L. genome along with their e-values identified from MCScanX.

Additional file 3: List of tandem and segmentally duplicated IQD genes in the G. hirsutum L. genome identified with MCScanX software.

Additional file 4: Divergence between paralogous IQD gene pairs in G. hirsutum $L$.

Additional file 5: Gene-specific primer pairs used in the qRT-PCR experiments. 


\section{Figures}

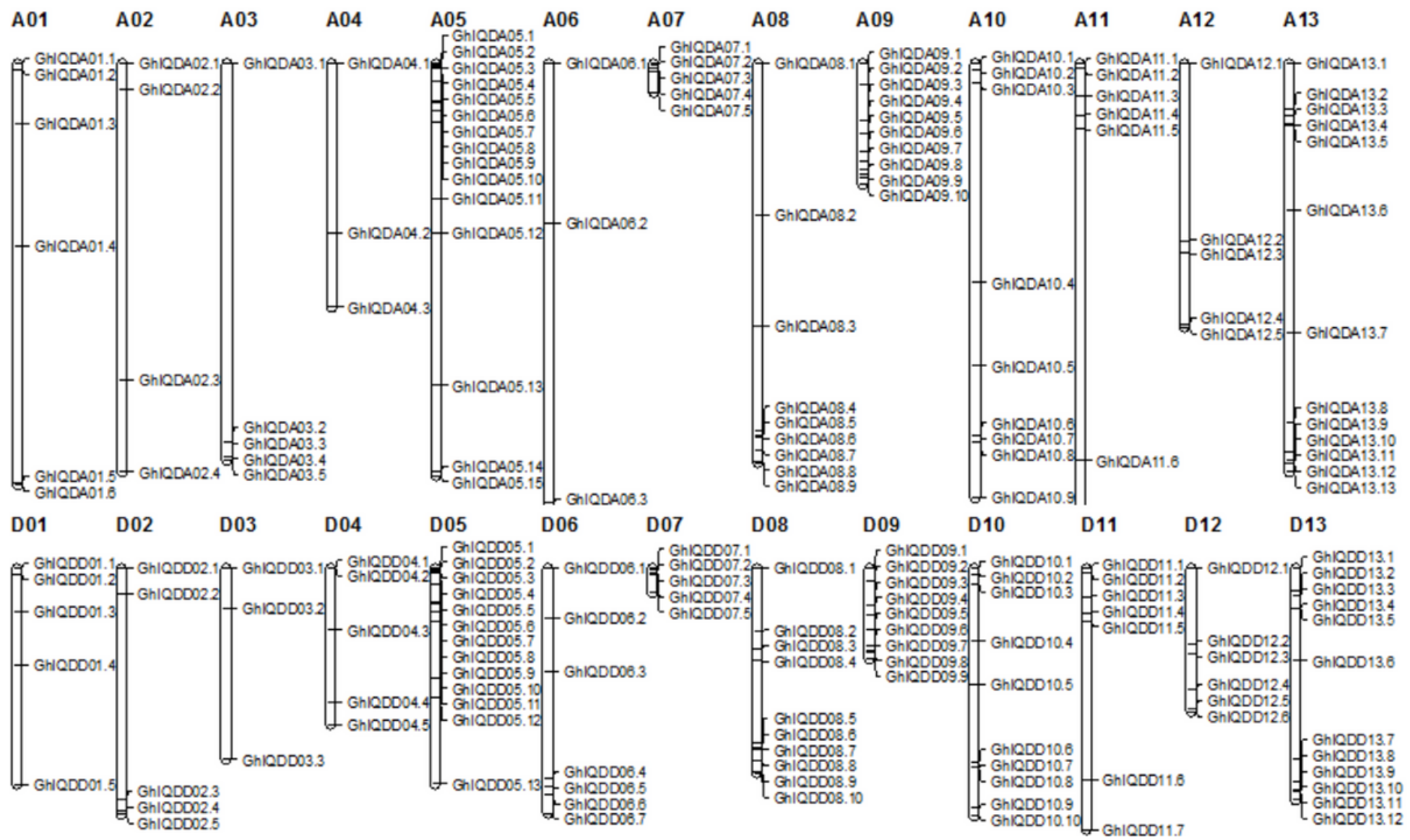

\section{Figure 1}

Chromosomal locations of cotton GhIQD genes on the $26 \mathrm{G}$. hirsutum L. chromosomes. A01-A13 and D01-D13 indicate chromosomes from the A-subgenome and D-subgenome, respectively. The chromosome number is shown above each chromosome, and the relative locations of the GhIQD genes are indicated on the chromosomes. 


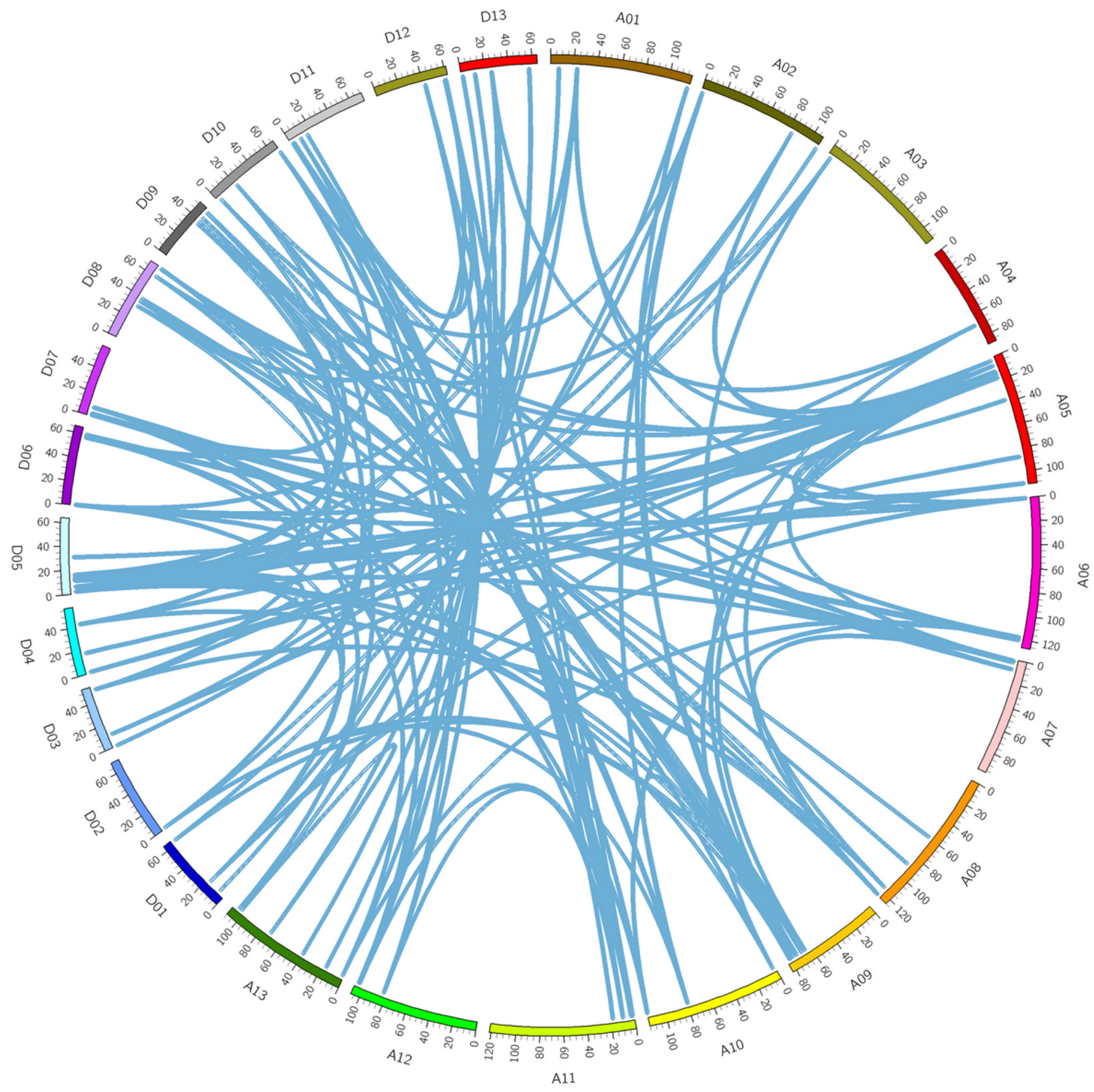

Figure 2

Circos figure of GhIQD gene pairs that arose from segmental duplication. The G. hirsutum L. chromosomes from the A- and D-subgenomes are shown in different colors, and the gene pairs involved in segmental duplication are linked by blue lines. The CIRCOS genome visualization tool was used to construct this figure. 


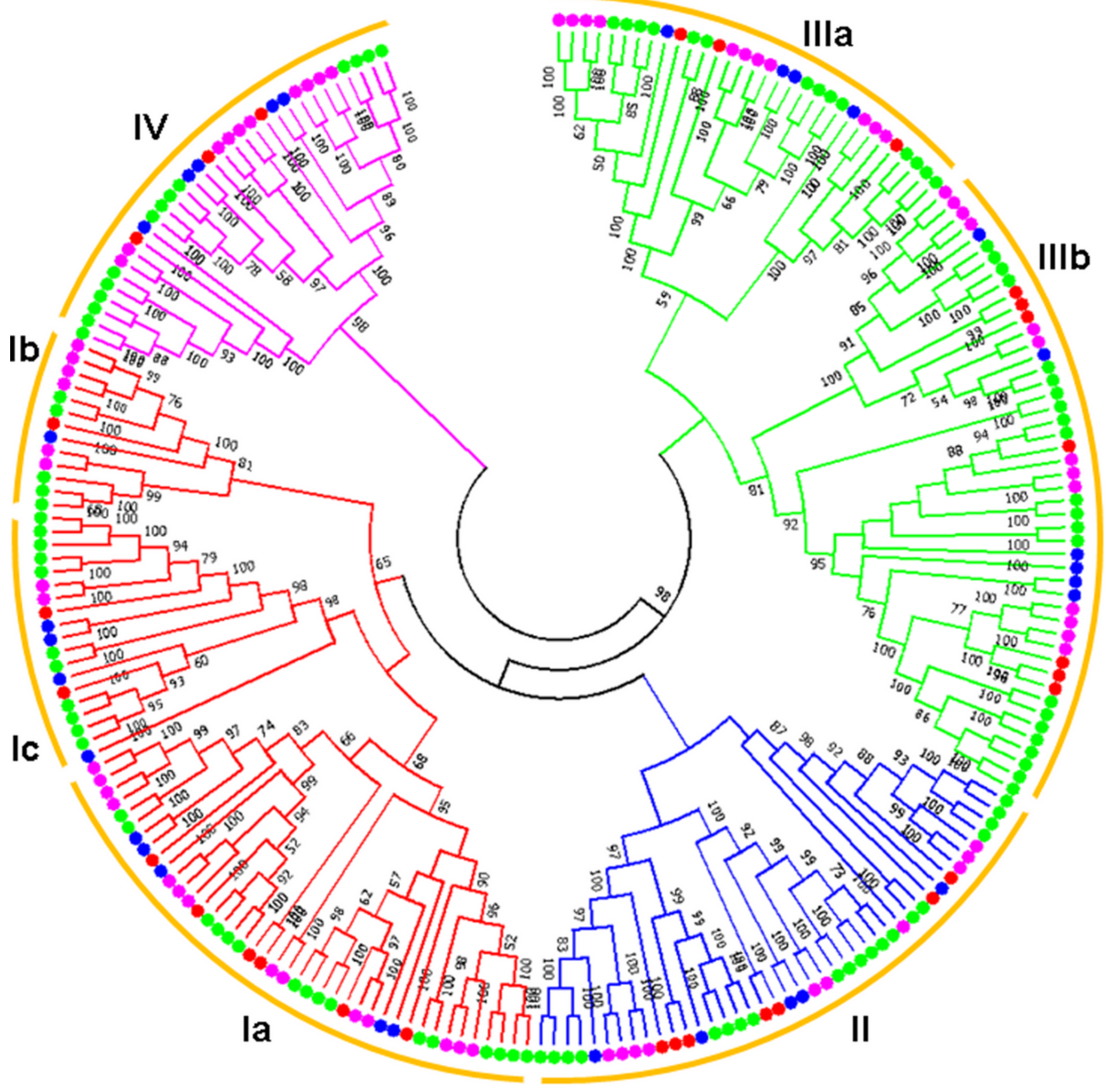

Figure 3

Phylogenetic and evolutionary analysis of IQD proteins from different plant species. Note, green dots indicate G. hirsutum L. IQD proteins; pink dots indicate soybean IQD proteins; red dots indicate IQD proteins from tomato; blue dots indicate Arabidopsis IQD proteins. The phylogenetic tree was generated from an alignment of the IQD protein sequences using the Neighbor-Joining $(\mathrm{NJ})$ method in the MEGA 7 software package. 
a.

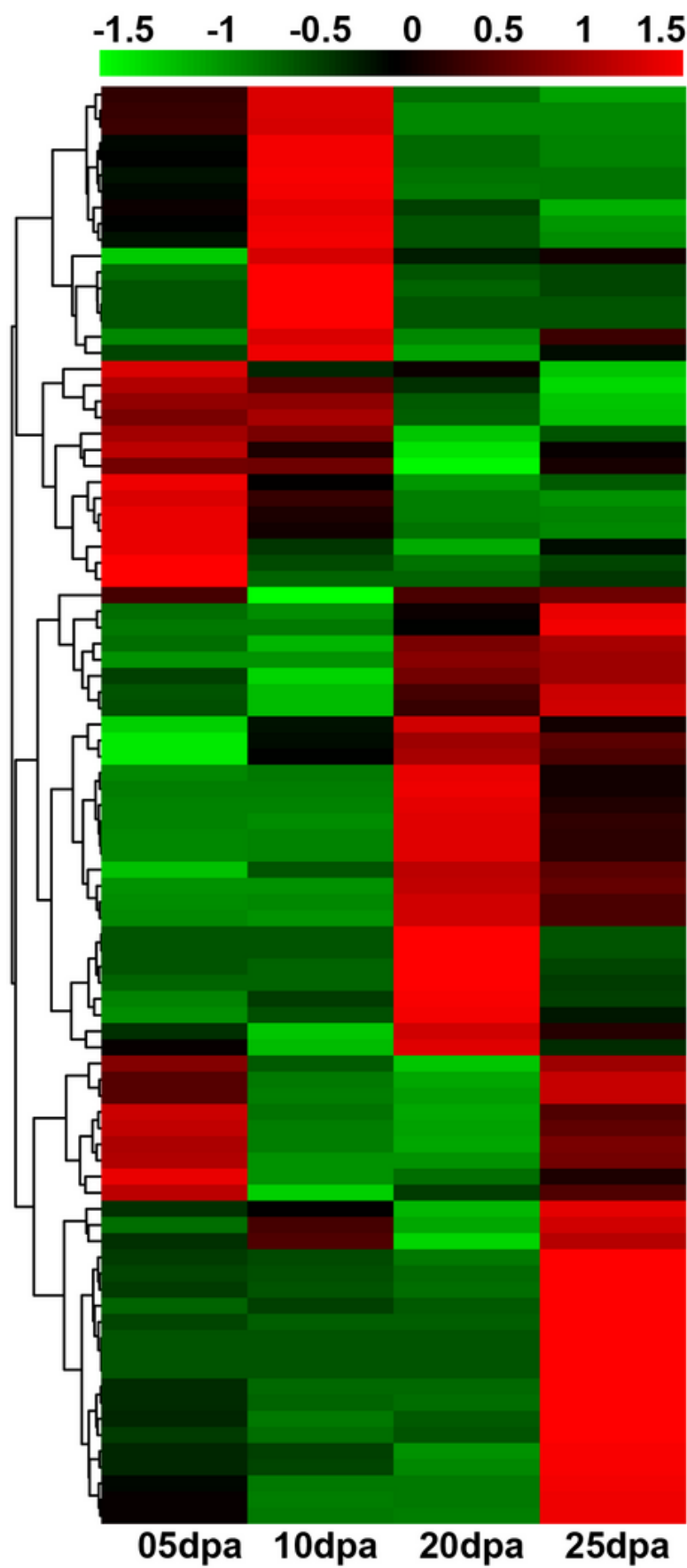

Cluster 1

(5)

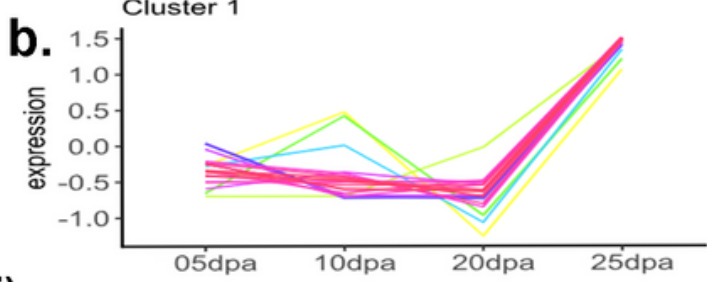

membership

0.9

0.8

0.7

0.6
0.5

(2)

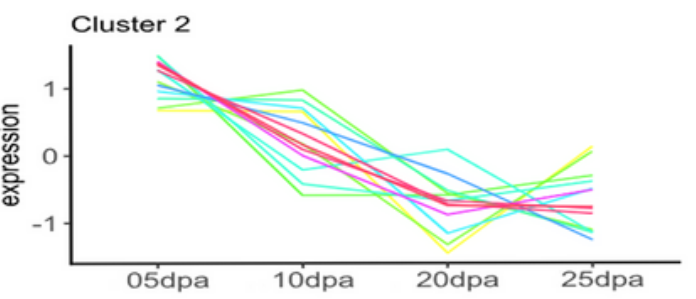

membership 0.8 0.6 0.4
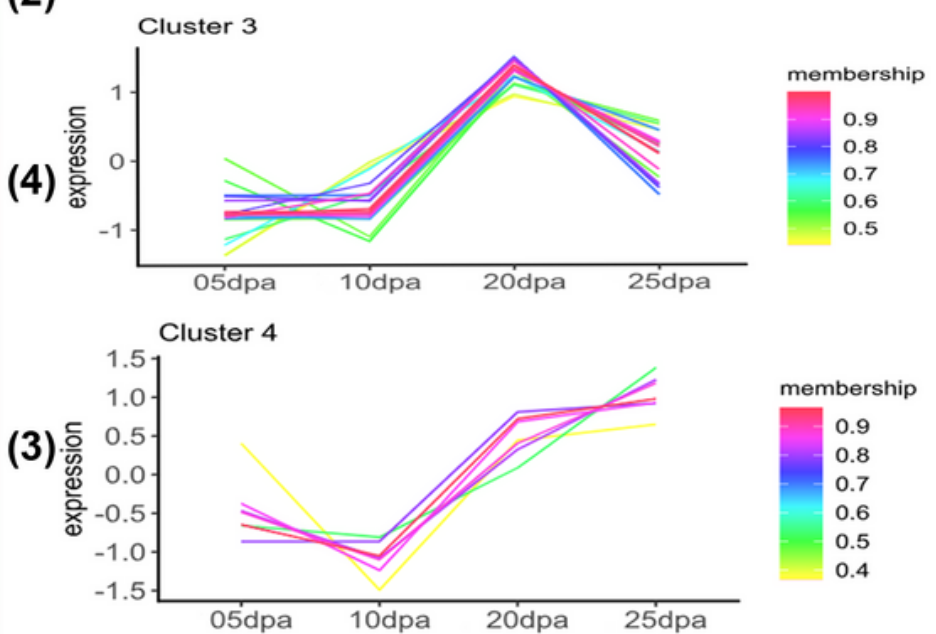

membership

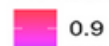

0.9

0.8
0.7

0.6

0.5

0.4

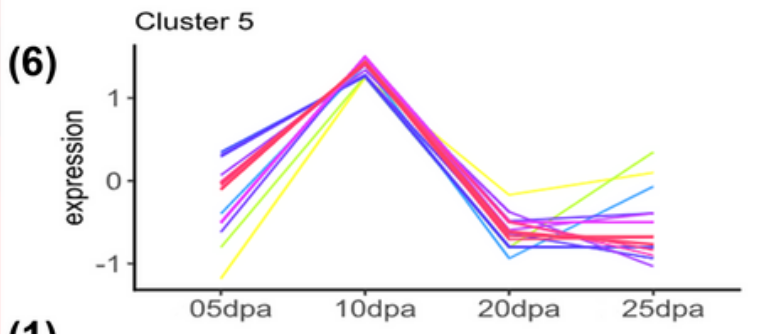

membership

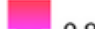

0.9

0.8

0.7

0.6

0.5

(1)

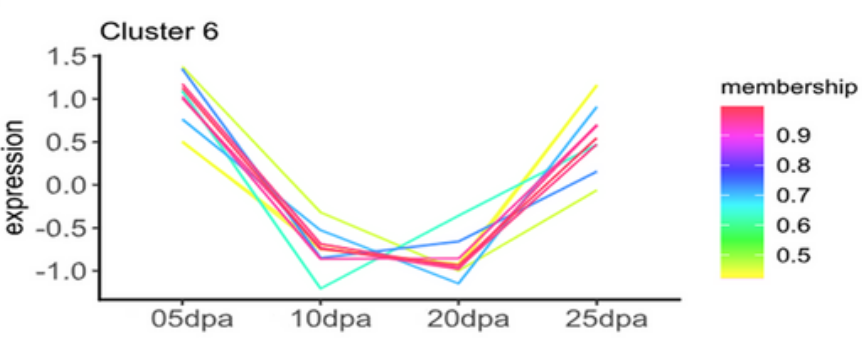

\section{Figure 4}

Expression profiling of GhIQD genes during four developmental stages of the cotton fiber cell. (a) A hierarchical clustering heatmap of GhIQD gene expression in fiber cells at 5, 10, 20, and $25 \mathrm{dpa}$. These data were obtained from the transcriptome data available on the Cottongen website (https://www.cottongen.org/). (b) Gene expression of 89 GhIQD genes in six different clusters during four developmental stages of cotton fiber cells. 




Figure 5

Tissue-specific expression analysis of 20 selected GhIQD genes by qRT-PCR. The relative expression levels of 20 GhIQD genes were examined by qRT-PCR assays and normalized to the expression level of the house-keeping gene GhHis3. The calyx, leaf, stigma, stem, root, petal, pollen, and hypocotyl tissues are indicated on the X-axis. Relative gene expression levels compared with the calyx are indicated on the $\mathrm{Y}$-axis, * represents a significant difference at the $p<0.05$ level, ** represents an extremely significant difference at the $p<0.01$ level. 


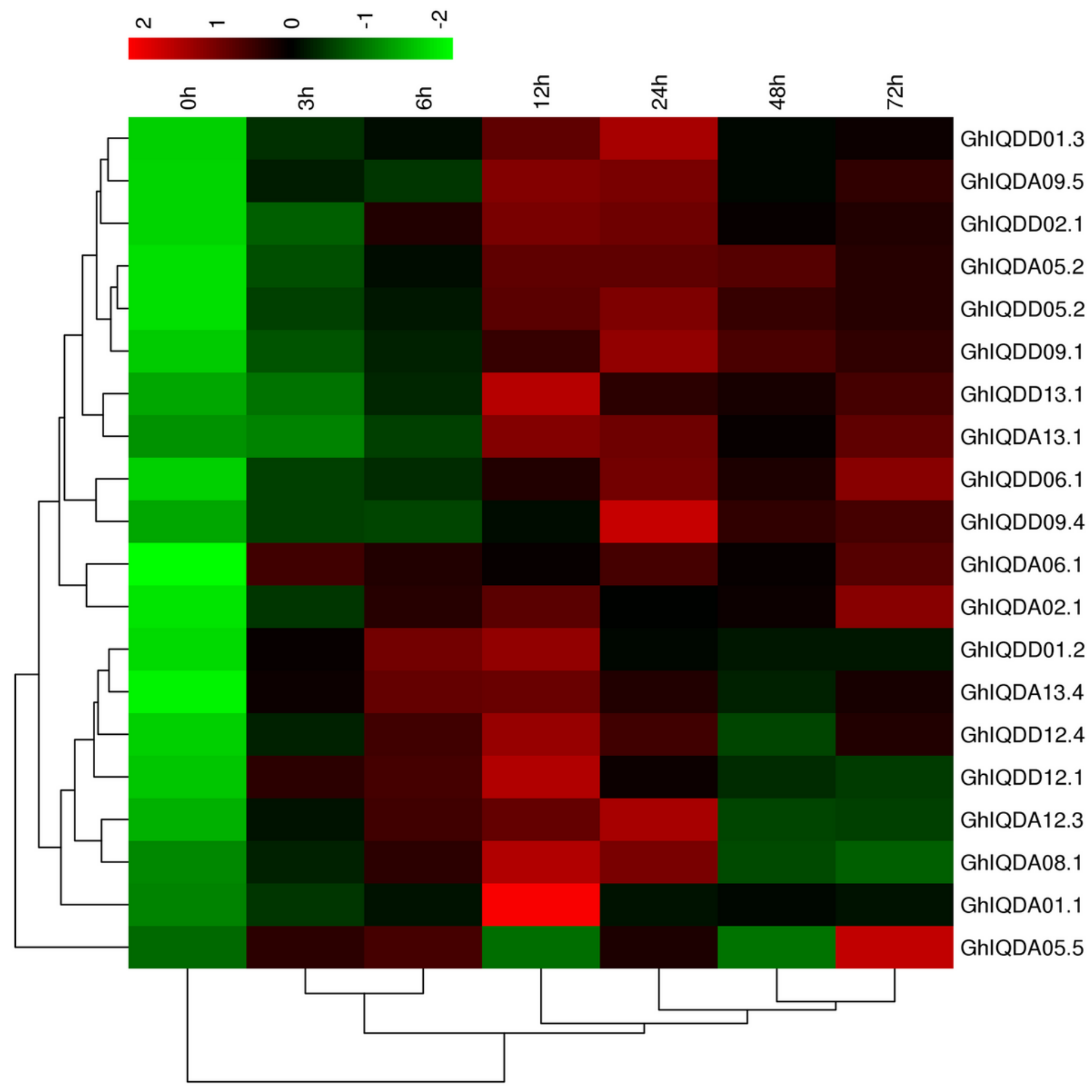

Figure 6

The expression profiles of 20 selected GhIQD genes in response to MeJA treatment at $0,3,6,12,24,48$, and $72 \mathrm{~h}$. The gene expression values were determined by qRT-PCR and calculated using the 2- $\triangle \triangle \mathrm{CT}$ method. The heatmap was drawn with Omicshare (https://www.omicshare.com/tools/Home/Soft/heatmap). The color scale on the top of the figure represents expression values computed by the $2-\Delta \Delta \mathrm{Ct}$ method. 


\section{Supplementary Files}

This is a list of supplementary files associated with this preprint. Click to download.

- Additionalfile2.xls

- Additionalfile5.xls

- Additionalfile3.xls

- Additionalfile1.xIs

- Additionalfile4.xls 